\title{
Evaluation of Spectral Overview and Radio Frequency Interference (RFI) Sources at Four Different Sites in CALLISTO Network at the Narrow Band Solar Monitoring Region
}

\author{
Z. S. Hamidi ${ }^{1, *}$, N. N. M. Shariff ${ }^{2}$, C. Monstein ${ }^{3}$ \\ ${ }^{1}$ School of Physics and Material Sciences, Faculty of Sciences, MARA University of Technology, \\ 40450, Shah Alam, Selangor, Malaysia \\ ${ }^{2}$ Academy of Contemporary Islamic Studies (ACIS), MARA University of Technology, \\ 40450, Shah Alam, Selangor, Malaysia \\ ${ }^{3}$ Institute of Astronomy, Wolfgang-Pauli-Strasse 27, Building HIT, Floor J, \\ $\mathrm{CH}-8093$ Zurich, Switzerland \\ *E-mail address: zetysh@salam.uitm.edu.my
}

\begin{abstract}
Continuous observation of solar radio burst in CALLISTO network was started since 2002 with Blein Switzerland is the first site that launched the system. Since then, there are more than 35 sites around the world that monitor the Sun activity within 24 hours until 2014. However, there is an issue of Radio Frequency Interference (RFI) that need to be considered. This noise is a major obstacle when performing observation with CALLISTO system. We selected 4 sites as preliminary analysis to analyze in detailed at a specific frequency which is very important in solar burst monitoring. The selected sites are (i) Blein, Switzerland (ii) Mauritius (iii) KASI Korea and (iv) ANGKASA, Malaysia. The regime narrow band that we focused are from (i) $72-75 \mathrm{MHz}$ (ii) band $145-153 \mathrm{MHz}$ (iii) $240-250 \mathrm{MHz}$ (iv) $320-330 \mathrm{MHz}$ (v) $406-410 \mathrm{MHz}$. The results of the sources of the RFI also will be highlighted. This work is was part of a larger study which focuses on a specific region that can be used for detailed investigation of solar burst. This issue of Radio Frequency Interference (RFI) needs a dialogue and interactions between different actors and networks.It is hoped that the analysis will help the solar physicist to choose a better data.
\end{abstract}

Keywords: CALLISTO; Radio Frequency Interference (RFI); RFI sources; solar radio burst

\section{INTRODUCTION}

The Radio Frequency Interference (RFI) is one of the main issues in solar monitoring in radio region. This noise is due to the technology application for human purpose. Continuous observation of solar radio burst in CALLISTO network was started since 2002 with Blein Switzerland is the first site that launched the system [1]. Since then, there are more than 35 sites around the world that monitor the Sun activity within 24 hours until 2014. We have 
started by proposing this research in early 2011, through the MARA University of Technology, University of Malaya, and the National University of Malaysia and as universities collaborator [2]. In previous work, some evaluation in terms of Radio Frequency Interference (RFI) indication has been done [3,4].

The main objective of this work is to investigate in detail what kind of sources that might affect the signal of the Sun. We also want to investigate either due to population density, which is specifically for the solar monitoring purpose [5]. There are many physical processes and propagation effects for the producing the time variable radio emission in radio region. It is very important because although the signal is intermittent, the solar burst signal can be exploded at any time. Therefore, we should concern about this issue.

\section{CALLISTO SYSTEM AND OBSERVATION}

E-Callisto network is one of the most outstanding project under the International Space Weather Initiative (ISWI) for solar monitoring study [6,7]. Malaysia becomes the 19th countries that involve this research. We have installed a solar radio spectrometer CALLISTO on February 2012 at the National Space Centre; Selangor, Malaysia. This noise is a major obstacle when performing observation with CALLISTO system. We selected 4 sites as preliminary analysis to analyze in detailed at a specific frequency which is very important in solar burst monitoring. It could not be denied that that the Earth environment has a close connection with Sun activities [8]. So far, we have productively obtained a good solar radio burst data associated with solar flares and Coronal Mass Ejections (CMEs) [9-11]. The impact of solar activities indirectly affected the conditions of earth's climate and space weather [12].

The strong progress in the development of the antenna, methods and instrumentation allowed to start the corresponding investigations at new quality and quantity levels. We construct the antenna with the length is about 5.45 meters and covers the range from $45-$ $870 \mathrm{MHz}$ with a gain of about $7 \mathrm{dBi}$. As a part of the system, we use a low noise preamplifier between the antenna and receiver [3]. During the installation, a the spectral overview analysis to know the quality of each site [13].

\section{RESULTS AND ANALYSIS}

This work is was part of a larger study which focuses on a specific region that can be used for detailed investigation of solar burst. The selected sites are (i) Blein, Switzerland (ii) Mauritius (iii) KASI Korea and (iv) ANGKASA, Malaysia. The regime narrow band that we focused are from (i) $72-75 \mathrm{MHz}$ (ii) band $145-153 \mathrm{MHz}$ (iii) $240-250 \mathrm{MHz}$ (iv) $320-$ $330 \mathrm{MHz}(\mathrm{v}) 406-410 \mathrm{MHz}$.

The results of the sources of the RFI also will be highlighted. Details spectral overview at specific region is illustrated in the Figure 1 - Figure 6. The calibration of RFI in solar burst data is very important to calculate the actual value of solar burst that associated with the solar flares and Coronal Mass Ejections (CMEs) associated with different types of solar bursts $[14,15]$. So far, we only focused on the short term variability of solar flare and CMEs events [16]. The data is then can be compared with an X-ray region data [17]. There are also other types such as type $\mathrm{U}, \mathrm{V}$ and IV that have been analyzed in detailed $[18,19]$. 


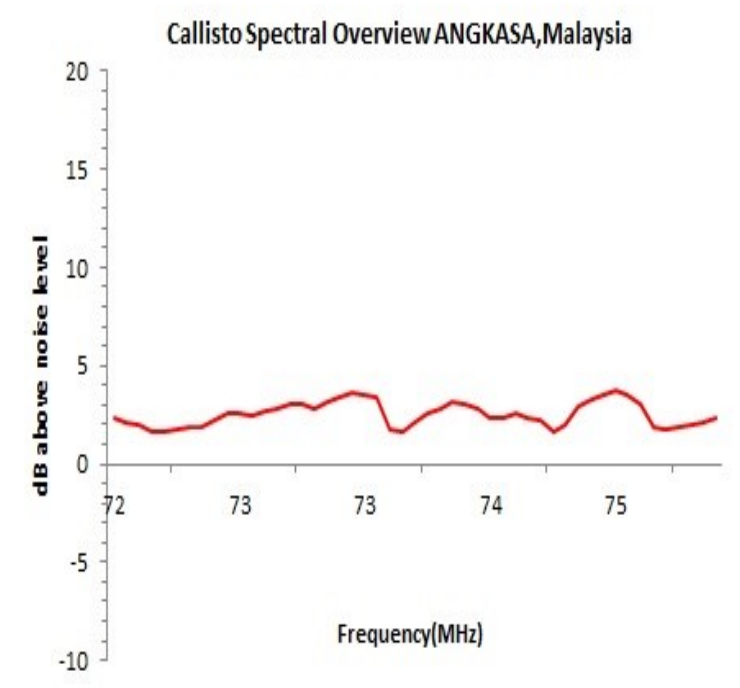

Callisto Spectral Overview Mauritius Radio Telescope


Figure 1. Spectral overview measured at four sites. Shared use of the radio astronomy band $72-75 \mathrm{MHz}$. 
Callisto Spectral overview in ANGKASA , Malaysia

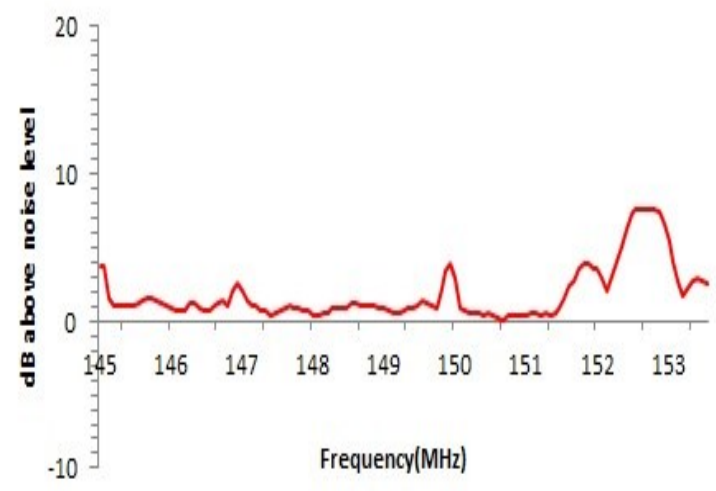

Callisto Spectral Overview in Mauritius Radio Telescope

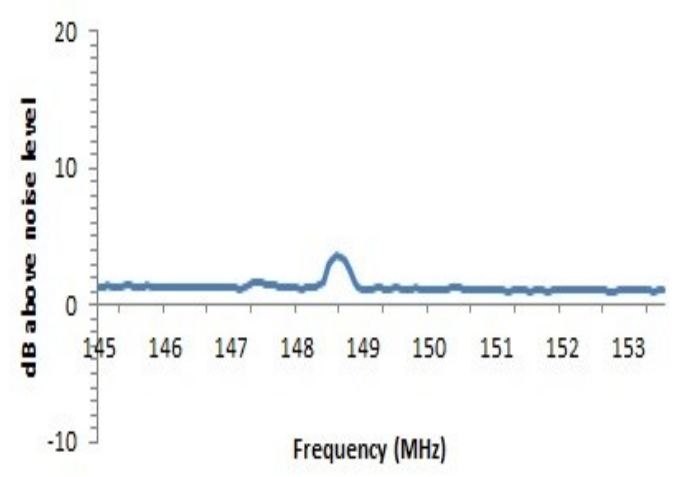

Frequency (MHz)

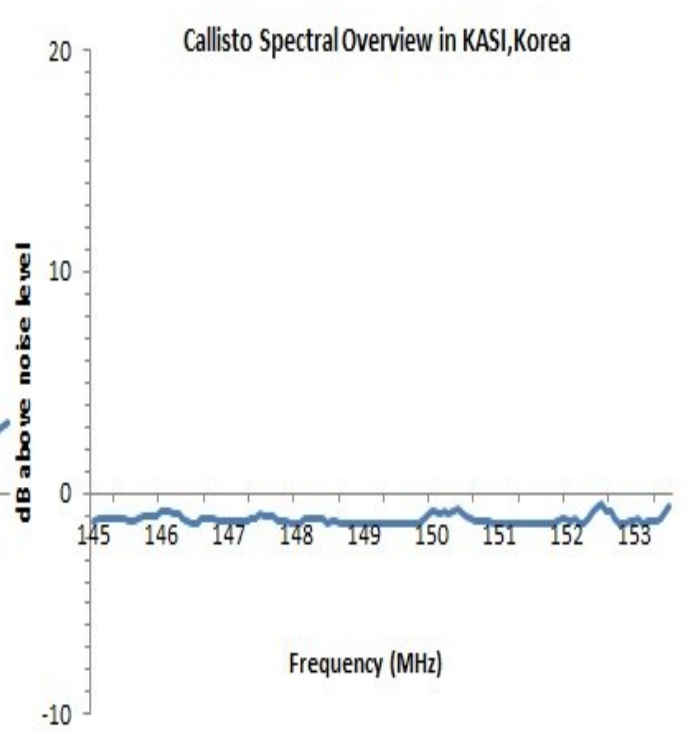

Figure 2. Spectral overview measured at four sites. Shared use of the radio astronomy band $145-153 \mathrm{MHz}$. 


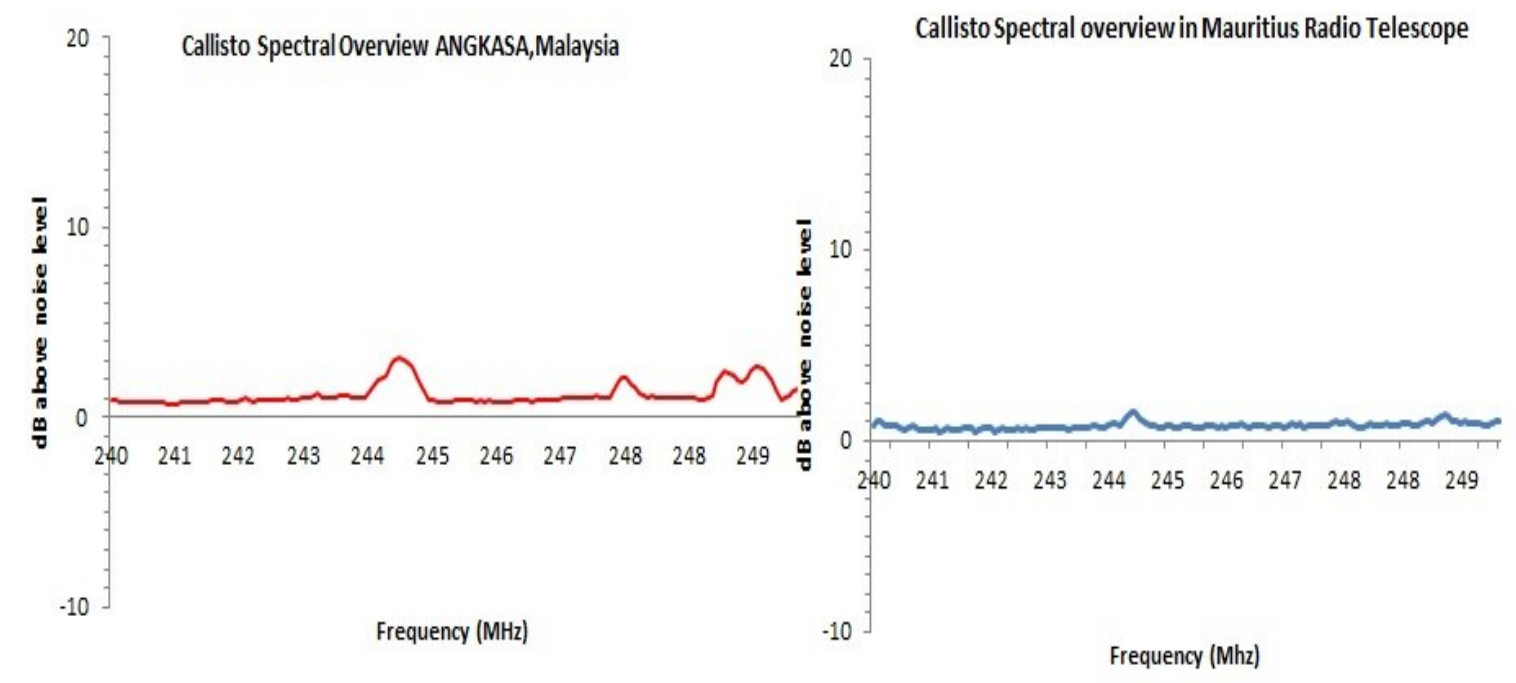

Callisto Spectral Overview in Blein,Switzerland

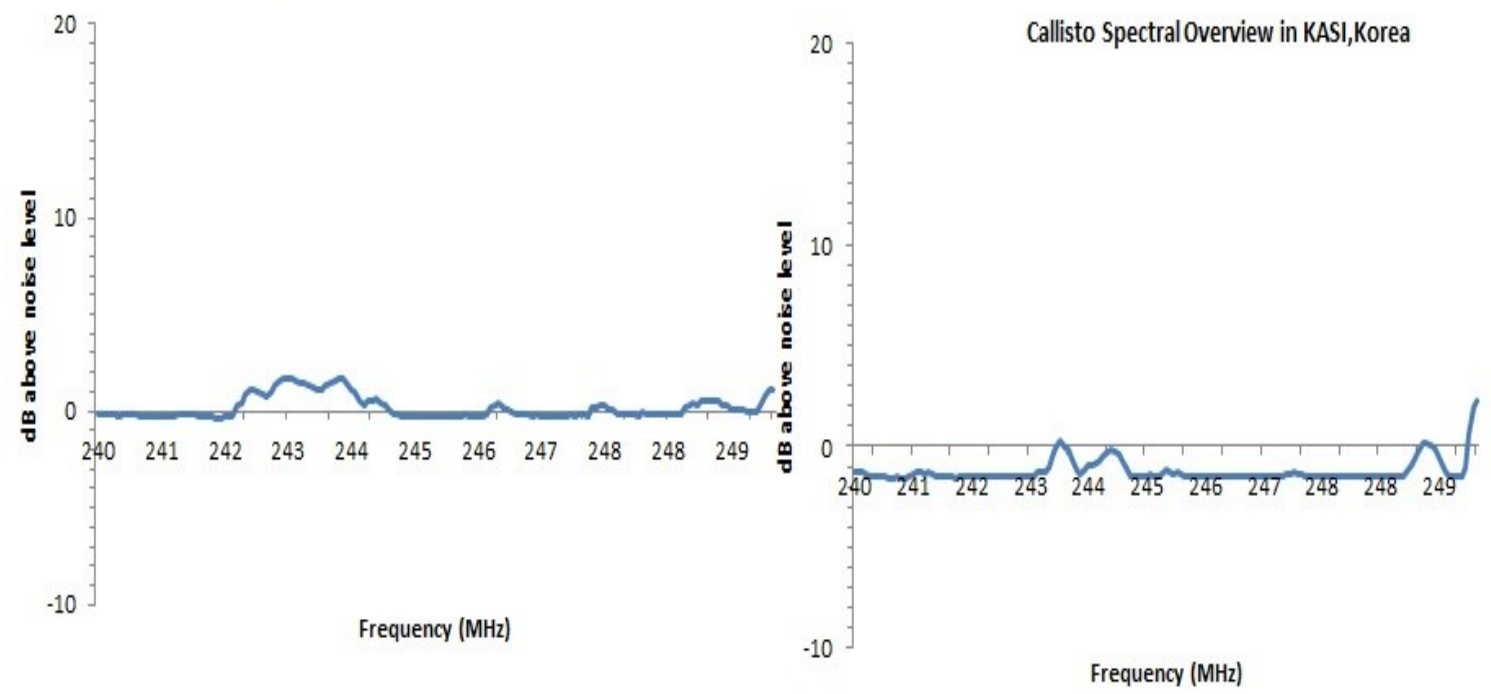

Figure 3. Spectral overview measured at four sites. Shared use of the radio astronomy band 240-250 MHz. 

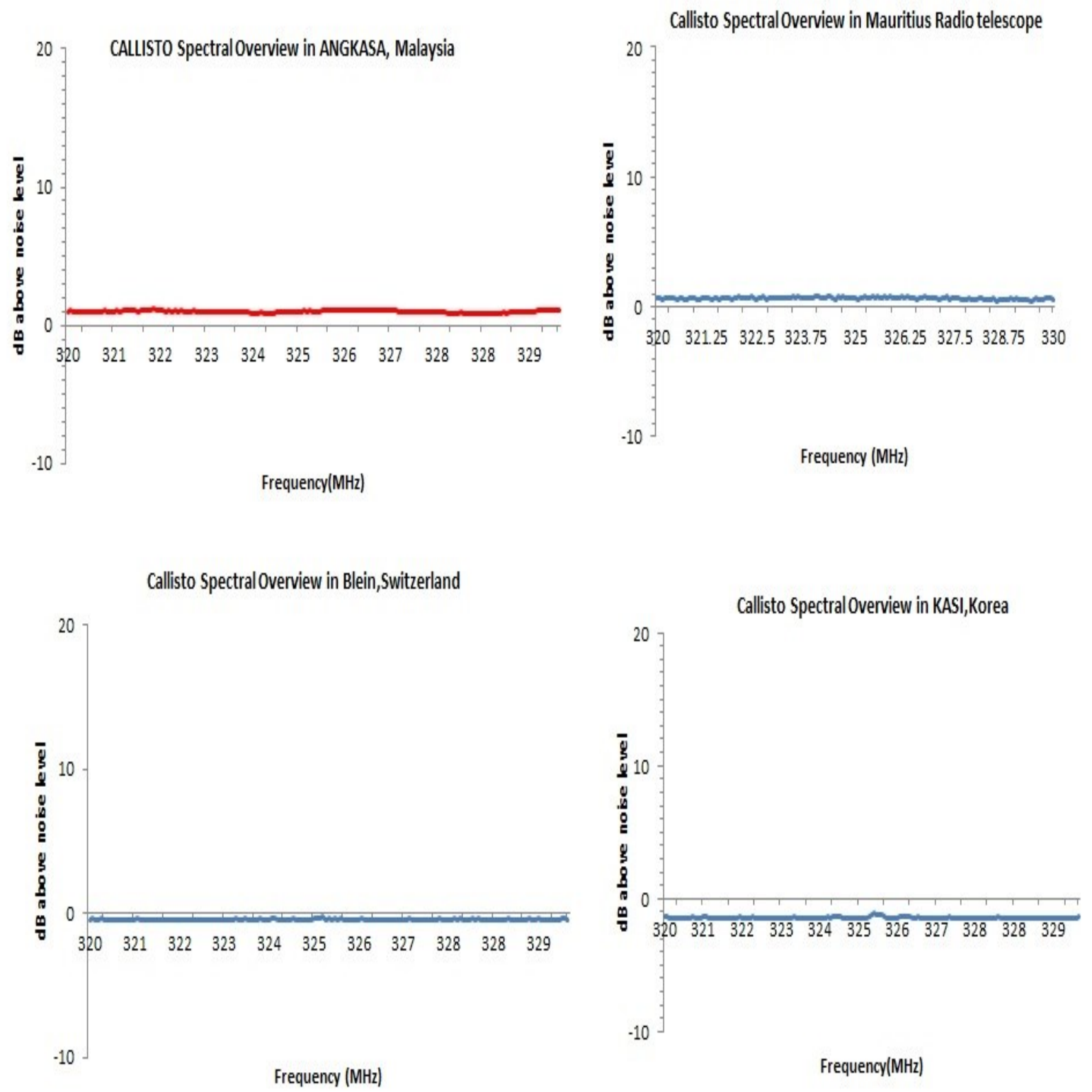

Figure 4. Spectral overview measured at four sites. Shared use of the radio astronomy band 320-330 MHz. 

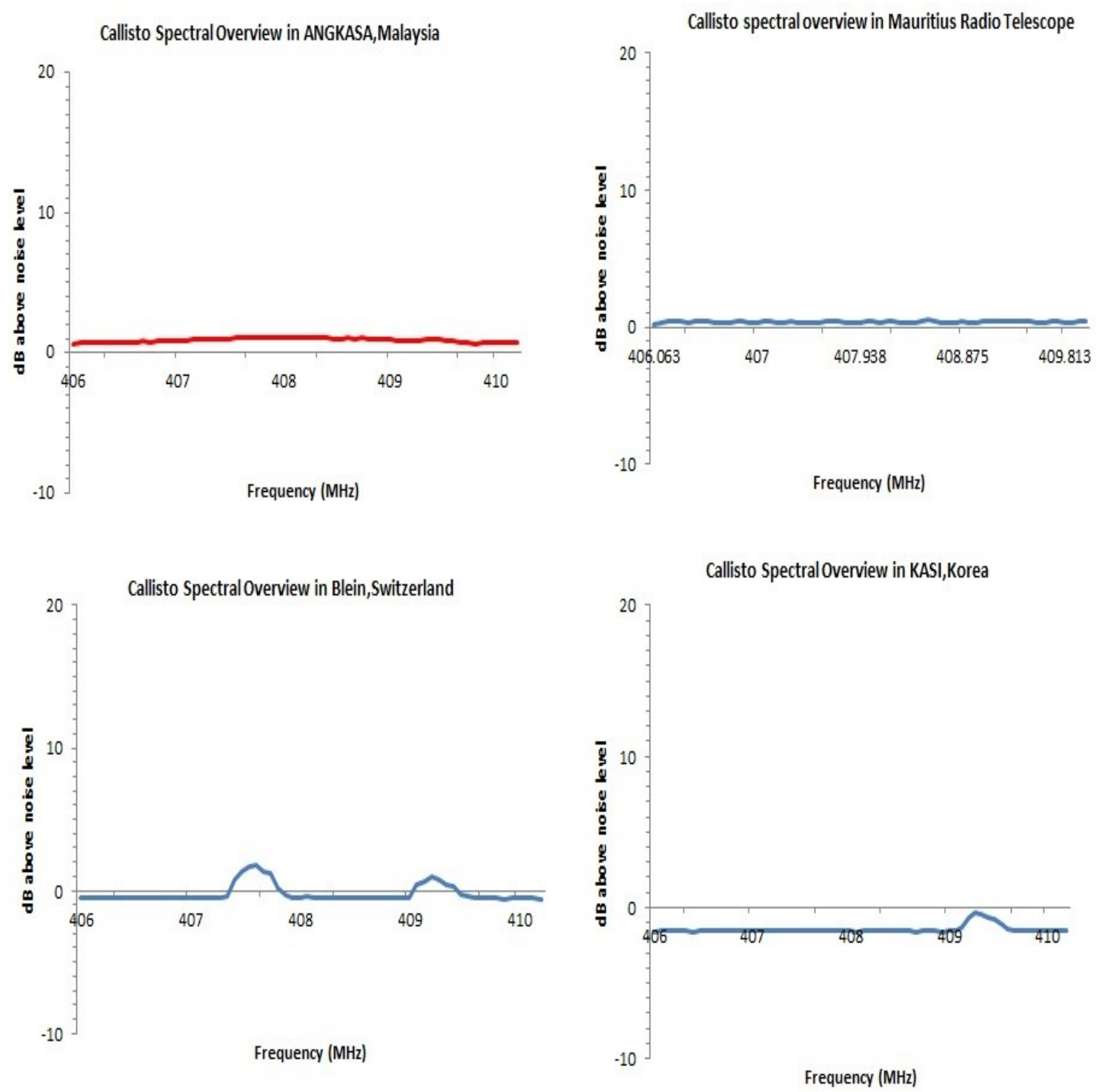

Figure 5. Spectral overview measured at four sites. Shared use of the radio astronomy band 406-410 MHz. 

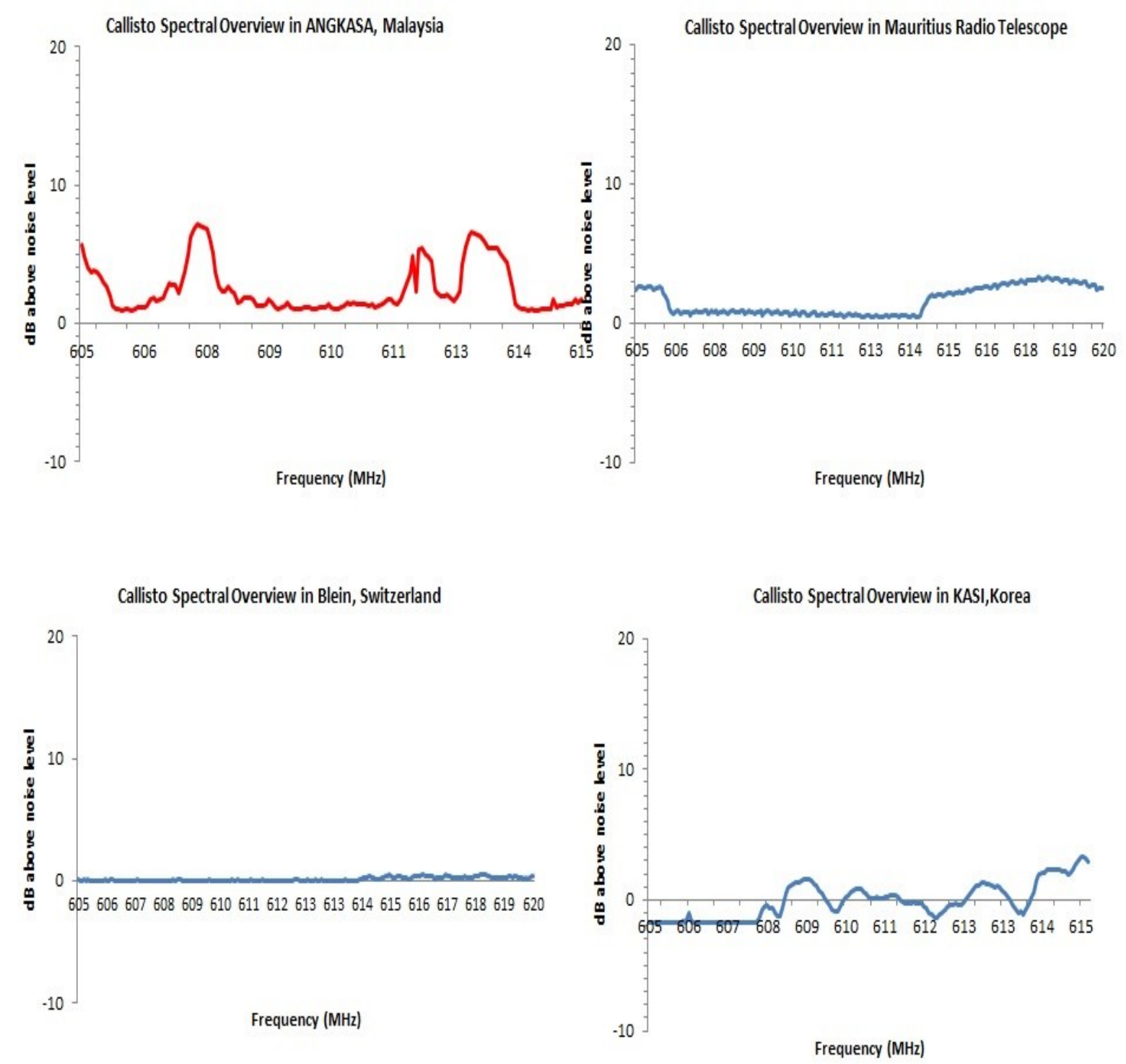

Figure 6. Spectral overview measured at four sites. Shared use of the radio astronomy band 605-615 MHz. 
Table 1. Lists the RFI sources at specific region for the four sites of e-CALLISTO network.

\begin{tabular}{|c|c|c|c|c|c|}
\hline $\begin{array}{l}\text { Frequency } \\
\text { (MHz) }\end{array}$ & $\begin{array}{c}\text { RFI } \\
\text { Sources }\end{array}$ & $\begin{array}{l}\text { ANGKASA, } \\
\text { Malaysia }\end{array}$ & Mauritius & $\begin{array}{c}\text { Blein, } \\
\text { Switzerland }\end{array}$ & KASI, Korea \\
\hline $72-75$ & $\begin{array}{l}\text { Local } \\
\text { electronic }\end{array}$ & $\begin{array}{c}\text { Radio } \\
\text { navigation }\end{array}$ & $\begin{array}{l}\text { Extremely } \\
\text { quiet }\end{array}$ & $\begin{array}{c}\text { Fixed/mobile } \\
\text { radio- } \\
\text { communication } \\
\text { users }(73.0-74.6)\end{array}$ & $\begin{array}{c}\text { TV Band III }(73 \mathrm{MHz} \\
\text { until } 74.6 \mathrm{MHz})\end{array}$ \\
\hline $145-153$ & $\begin{array}{l}\text { Communicat } \\
\text { ion traffic }\end{array}$ & Broadcasting & $\begin{array}{c}150.05 \mathrm{MHz} \\
\text { until } 153 \mathrm{MHz} \\
\text { Primary use in } \\
\text { the West } \\
\text { foreseen for } \\
\text { radio } \\
\text { astronomy. } \\
\text { This may be a } \\
\text { case for local } \\
\text { OFCOM or } \\
\text { CRAF. }\end{array}$ & $\begin{array}{c}\text { Weak signal at } 149 \\
\text { MHz shared with } \\
\text { other service }\end{array}$ & $\begin{array}{l}150.05 \mathrm{MHz} \\
\text { (communication } \\
\text { traffic) until 153Mhz } \\
\text { are reserved for radio } \\
\text { astronomy and they } \\
\text { are not free from } \\
\text { interference. }\end{array}$ \\
\hline $240-250$ & $\begin{array}{l}\text { Other } \\
\text { services }\end{array}$ & $\begin{array}{l}\text { Aeronautical } \\
\text { navigation } \\
245.5 \mathrm{MHz}, \\
248.7 \mathrm{MHz} \text { and } \\
249 \mathrm{MHz}\end{array}$ & $\begin{array}{l}245 \mathrm{MHz}: \\
\text { other services } \\
\text { in the West }\end{array}$ & $\begin{array}{l}\text { Free from } \\
\text { Interference }\end{array}$ & $\begin{array}{l}245 \mathrm{MHz} \text { is a fixed } \\
\text { frequency for the } \\
\text { measurement of quiet } \\
\text { sun flux but shared } \\
\text { with other services in } \\
\text { the West. }\end{array}$ \\
\hline $320-330$ & $\begin{array}{l}\text { Free from } \\
\text { Interference }\end{array}$ & $\begin{array}{c}\text { Free from } \\
\text { Interference }\end{array}$ & $\begin{array}{c}\text { Free from } \\
\text { Interference }\end{array}$ & $\begin{array}{c}\text { Free from } \\
\text { Interference }\end{array}$ & $\begin{array}{c}\text { (322 MHz until } 328.6 \\
\mathrm{MHz} \text { ) bad due to a } \\
\text { strong nearby pager } \\
\text { transmitter }\end{array}$ \\
\hline $406-410$ & $\begin{array}{l}\text { A weak } \\
\text { signal } \\
\text { outside of } \\
\text { the RA band }\end{array}$ & $\begin{array}{c}\text { Free from } \\
\text { Interference }\end{array}$ & $\begin{array}{l}402 \mathrm{MHz} \text { : } \\
\text { there is a weak } \\
\text { signal outside } \\
\text { of the RA band }\end{array}$ & $\begin{array}{l}\text { Free from } \\
\text { Interference }\end{array}$ & $\begin{array}{l}\text { Low interference } \\
\text { level } 409 \mathrm{MHz} \\
\text { There is a weak } \\
\text { signal in the middle } \\
\text { of the RA band. }\end{array}$ \\
\hline $605-615$ & $\begin{array}{c}\text { A weak } \\
\text { signal } \\
\text { outside of } \\
\text { the RA band }\end{array}$ & Fixed mobile & $\begin{array}{l}602.5 \mathrm{MHz}: \text { is } \\
\text { some weak } \\
\text { interference }\end{array}$ & $\begin{array}{c}\text { Free from } \\
\text { Interference }\end{array}$ & $\begin{array}{c}\text { High level of } \\
\text { interference in } \\
\text { Daejeon due to } \\
\text { analog Tvon the left } \\
\text { and DVB-T on the } \\
\text { right. }\end{array}$ \\
\hline
\end{tabular}

In conducting the case studies and for better data analyses, we identify each sources of RFI in details. Table 1 lists the RFI sources at specific region for the four sites of eCALLISTO network. Each site shows a weak and strong of noise. It is not easy to conclude which site is the best and low of interference. However, we still possible to choose by looking the average of the signal. Most of the RFI sources can be found in the region less than 250 $\mathrm{MHz}$. Nevertheless, there is still a region that is free from interference.

One interesting fact to point out is that in the region $320-330 \mathrm{MHz}$, three out of the four sites have a very minimum of noise. This region is very good to detect type II and type III solar burst. In the region below of $100 \mathrm{MHz}$, most applications are used for the radio communication purpose. It is still possible to detect a good data of solar burst at the region more than $300 \mathrm{MHz}$ and above. This range is possible to detect solar burst type (I-V). 


\section{CONCLUSION}

This issue of Radio Frequency Interference (RFI) needs a dialogue and interactions between different actors and networks. Although the application of technology becomes more demanding, radio astronomy should be the first priority in exploration of the Universe because this range is the potential range that can tell us more comprehensive of celestial object with the wide coverage of electromagnetic spectrum compare the others. The specific range for radio astronomy purpose should be sustain and cannot be used for other application. This is very important for us to realize it. It is hoped that the analysis will help the solar physicist to choose a better data.

\section{ACKNOWLEDGEMENT}

We are grateful to e-CALLISTO network that make their data available online. This work was partially supported by the FRGS (600 RMI/FRGS 5/3 2012) UiTM grants. Special thanks to the National Space Agency and the National Space Centre for giving us a site to set up this project and support this project. Solar burst monitoring is a project of cooperation between the Institute of Astronomy, ETH Zurich, and FHNW Windisch, Switzerland, MARA University of Technology and University of Malaya. This paper also used NOAA Space Weather Prediction Centre (SWPC) for the sunspot, radio flux and solar flare data for comparison purpose. The research has made use of the National Space Centre Facility and a part of an initiative of the International Space Weather Initiative (ISWI) program.

\section{BIOGRAPHY}

Dr. Zety Sharizat Hamidi is currently a lecturer and focused in Solar Astrophysics research specifically in radio astrophysics at the School of Physics and Material Sciences, Faculty of Sciences, MARA University of Technology, 40450, Shah Alam, Selangor, Malaysia. Involve a project under the International Space Weather Initiative (ISWI) and also a lecturer in School of Physics and Material Science, at MARA University of Technology, Shah Alam Selangor.

Dr. Nur Nafhatun Md Shariff is a senior lecturer in Academy of Contemporary Islamic Studies (ACIS), MARA University of Technology, 40450, Shah Alam, Selangor, MalaysiaHer current research is more on sustainability; environmental aspect. She is looking forward for cross-field research, i.e. solar astrophysics, light pollution measurement (mapping) and religious studies.

C. Monstein is a senior Engineer at Institute of Astronomy, Wolfgang-Pauli-Strasse 27, Building HIT, Floor J, CH-8093 Zurich, Switzerland and one of the researchers who initiated the CALLISTO system around the world.

\section{References}

[1] A.O. Benz, M. Guedel, H. Isliker, S. Miszkowicz, W. Stehling, Sol. Phys. 133 (1991) 385-393.

[2] Z.S. Hamidi, N.N.M. Shariff, Z.Z. Abidin, Z.A. Ibrahim, C. Monstein, Malaysian Journal of Science and Technology Studies 9 (2013) 15-22.

[3] Z.S. Hamidi, Z.Z. Abidin, Z.A. Ibrahim, N.N.M. Shariff, Indication of radio frequency interference (RFI) sources for solar burst monitoring in Malaysia, AIP Conference Proceedings 1454 (2012) 43. 
[4] N. Anim, Z.S. Hamidi, Z.Z. Abidin, C. Monstein, N. Rohizat, Radio frequency interference affecting type III solar burst observations, PERFIK 2012, AIP Publisher, Pahang Malaysia, 2012, pp. 5.

[5] Roslan Umar, Zamri Zainal Abidin, Zainol Abidin Ibrahim, Mohd Saiful Rizal Hassan, Zulfazli Rosli, Z.S.Hamidi, Population density effect on radio frequencies interference (RFI) in radio astronomy, ICPAP 2012, AIP Conference Proceedings, Bandung Indonesia, 2012, pp. 4.

[6] Benz A.O., C. Monstein, H. Meyer, CALLISTO, A New Concept for Solar Radio Spectrometers, Kluwer Academic Publishers, 2004.

[7] A.O. Benz, C. Monstein, H. Meyer, P.K. Manoharan, R. Ramesh, A. Altyntsev, A. Lara, J. Paez, K.-S. Cho, Earth Moon and Planets 104 (2009) 277-285.

[8] Z.S. Hamidi, N.N.M. Shariff, C. Monstein, Z. Abidin, Z. Ibrahim, N. Hashim, R. Umar, N. Aziz, International Journal of Fundamental Physical Sciences 3 (2013) 57-63.

[9] Z.S.Hamidi, N.M.Anim, N. N.S.Hakimi, N.Hamzan, A.Mokhtar, N.Syukri, S.Rohizat, I.Sukma, Z.A. Ibrahim, Z.Z.Abidin, N.N.M.Shariff, C.Monstein, International Journal of Fundamental Physical Sciences 2 (2012) 4.

[10] Z.S.Hamidi, Z. Abidin, Z. Ibrahim, N. Shariff, C. Monstein, Observations of coronal mass ejections (CMEs) at low frequency radio region on 15th April 2012, in: R. Shukor (Ed.), PERFIK 2012, American Institute of Physics, Malaysia, 2013, pp. 5.

[11] Z.S. Hamidi, N. Anim, N.N.M. Shariff, Z.Z. Abidin, Z.A. Ibrahim, C. Monstein, Dynamical structure of solar radio burst type III as evidence of energy of solar flares, in: R.Shukor (Ed.), PERFIK 2012, American Institute of Physics, Malaysia, 2013, pp. 11-15.

[12] Z.S. Hamidi, N.N.M.Shariff, C.Monstein, Z.A. Ibrahim, International Letters of Chemistry, Physics and Astronomy 7 (2014) 37-44.

[13] C. Monstein, R. Ramesh, C. Kathiravan, Bull. Astr. Soc. India 35 (2007) 473-480.

[14] Z.S. Hamidi, N.N.M. Shariff, Thermal Energy and Power Engineering 3 (2014) 181-184.

[15] Z.S. Hamidi, N.N.M.Shariff, International Letters of Chemistry, Physics and Astronomy 4 (2014) 29-36.

[16] Z.S. Hamidi, N.N.M. Shariff, M.F. Ali, C. Monstein, W.N.A.W. Zulkifli, M.B. Ibrahim, N.S. Arifin, N.A. Amran, International Letters of Chemistry, Physics and Astronomy 9 (2014) 84-92.

[17] Z.S. Hamidi, N.N.M.Shariff, C.Monstein, W.N.A.W. Zulkifli, M.B. Ibrahim, N.S. Arifin, N.A. Amran, International Letters of Chemistry, Physics and Astronomy 8 (2014) 13-19.

[18] Z.S. Hamidi, N.N.M.Shariff, International Letters of Chemistry, Physics and Astronomy 7 (2014) 30-36.

[19] Z.S. Hamidi, N.N.M.Shariff, International Letters of Chemistry, Physics and Astronomy 5 (2014) 32-42. 